\title{
Overview and Classification of Conjunctival and Corneal Tumors
}

\author{
Raksha Rao and Carol L. Shields
}

\section{Overview and Classification}

Tumors affecting the conjunctiva and cornea include benign and malignant neoplasms arising from the conjunctival epithelium, conjunctival stroma, and structures within the stroma including the blood vessels, nerves, fat, and lymphoid tissue. Corneal tumors can arise specifically from the corneal epithelium and rarely does the stroma promote a tumor. Most corneal tumors are secondary to extension from an adjacent conjunctival tumor.

The first step in the management of a conjunctival tumor is to take a detailed history regarding the onset, previous precursors, rate of growth, and presence of symptoms such as pain or irritation. The second step is proper evaluation by external examination and slit lamp biomicroscopy. Tumor color, size, location, extension into the orbit or globe, and presence of related features like cysts, feeder, and intrinsic vessels, relationship to the limbus or fornix, and others should be recorded. In many instances, the clinician can differentiate malignant from benign tumors by history and examination. Following thorough clinical evaluation, ancillary testing with external photography,

R. Rao

Department of Orbit and Ophthalmic Oncology,

Narayana Nethralaya, Bangalore, India

C. L. Shields $(\bowtie)$

Ocular Oncology Service, Wills Eye Hospital,

Thomas Jefferson University, Philadelphia, PA, USA anterior segment photography, anterior segment optical coherence tomography (AS-OCT), ultrasound biomicroscopy, and incisional or excisional biopsy are all important in achieving an accurate diagnosis. Treatment of conjunctival tumors requires a basic understanding of the biological behavior and the tumor response to currently available therapeutic modalities including surgery, chemotherapy, immunotherapy, and radiotherapy. In this chapter, some of the common benign and malignant tumors of the conjunctiva and their management are presented.

Conjunctival tumors are relatively infrequent [1-5]. An epidemiologic review of 125 patients with ocular cancers from the Singapore Cancer Registry found only 16 (13\%) with a conjunctival tumor [3]. In a histopathology review of 2455 biopsied conjunctival lesions in adults at a tertiary referral center, Grossniklaus et al. identified a broad spectrum of lesions including inflammatory, degenerative, and pseudotumors (lesions simulating neoplasm) to represent $53 \%(n=1292)$ of cases, while true tumors represented $47 \%$ $(n=1163$ ) [4]. Among the tumors, the most common included acquired epithelial tumors (26\%), pigmented tumors (13\%), acquired subepithelial tumors (6\%), and congenital tumors (2\%) [4]. By contrast, in a clinical study from an ocular oncology tertiary referral center, pigmented (melanocytic) conjunctival tumors were found to be most common [5]. Shields et al. described 1643 conjunctival lesions, among which 872 (53\%) were 
melanocytic tumors, including nevus, primary acquired melanosis, and melanoma [5]. Even in the pediatric population, melanocytic tumors are the most common tumor in a clinical practice as Shields et al. reviewed 262 children and noted the leading tumors included melanocytic (67\%), choristomatous (10\%), vascular (9\%), and benign epithelial tumors $(2 \%)$, as well as other miscellaneous lesions $(10 \%)$ [6, 7].

Recent mega-data on over 5000 conjunctival tumors confirmed that melanocytic nevus was the most common conjunctival tumor $(1163 / 5002,23 \%)$ [8]. Other common tumors were primary acquired melanosis (623/5002, $12 \%)$, melanoma $(612 / 5002,12 \%)$, and squamous cell carcinoma (440/5002, 9\%) [8]. A separate analysis of this mega-data on pediatric conjunctival tumors in 806 cases disclosed that melanocytic $(492 / 806,61 \%)$ followed by choristomatous tumors $(65 / 806,8 \%)$ were the most common tumors in this age group [9]. In the overall group, comparative analysis of patients with primary acquired melanosis versus melanoma in 1224 cases found those with melanoma more likely showing tarsal location (relative risk $[R R]=1.6)$, thickness $>1 \mathrm{~mm}(\mathrm{RR}=2.8)$, presence of intralesional cysts $(R R=2.1)$, feeder vessels $(R R=2.3)$, intrinsic vessels $(R R=2.2)$, and hemorrhage $(\mathrm{RR}=1.8)$ [8]. Comparative analysis of patients with conjunctival intraepithelial neoplasia versus squamous cell carcinoma in 715 cases found those with squamous cell carcinoma more likely showing greater diffuse involvement $(p<0.0001)$, median basal diameter $(p<0.0001)$ and thickness $(p<0.0001)$, location $>1 \mathrm{~mm}$ from the limbus $(p=0.0228)$, brown pigmentation $(p=0.0264)$, and intrinsic vessels $(p=0.0234)$ [8]. Similarly, in children, nevus versus melanoma revealed melanoma more likely with greater tumor thickness ( $p=0.037$ ) and base $(\mathrm{RR}=4.92)$, presence of tumor hemorrhage $(R R=25.3)$, and absence of intrinsic cysts $(\mathrm{RR}=5.06)$, and lymphoid hyperplasia versus lymphoma revealed lymphoma more likely with larger mean basal dimension $(p=0.002)$ and diffuse in location vs nasal $(\mathrm{RR}=16.5)$ [9].

Conjunctival tumors are classified based on the type of tissue that they arise from including conjunctival epithelium, melanocytes, blood vessels, nerves, adipose tissue, and lymphoid tissue. They can also be classified as melanocytic and non-melanocytic tumors, or as benign and malignant tumors. In the following paragraphs, we will discuss the various conjunctival tumors based on major grouping including choristomatous, epithelial, melanocytic, vascular, neural, xanthomatous, myxomatous, lipomatous, lymphoid, leukemic, caruncular, metastatic, and secondary tumors (Table 6.1).

\section{Conjunctival Choristomas}

Conjunctival choristoma is a tumor composed of tissues not normally present in the conjunctiva. A simple choristoma contains only one type of tissue, whereas a complex choristoma contains more than one type [10]. Choristomas form a minority of lesions in adults but are the second most common conjunctival tumors found in children after melanocytic tumors [5, 6]. Examples of choristomas include dermoid, osseous, lacrimal gland, respiratory, and complex choristomas. Most choristomas remain stable with little potential for malignant transformation.

\section{Conjunctival Epithelial Tumors}

Conjunctival epithelial tumors encompass a wide spectrum of conjunctival and corneal squamous cell proliferation including benign squamous papilloma, keratoacanthoma, hereditary benign intraepithelial dyskeratosis, dacryoadenoma, intraepithelial neoplasia, and malignant squamous cell carcinomas (SCC). Papillomas constitute approximately $1 \%$ of all lesions and are associated with human papillomavirus (HPV) in up to $81 \%$ of cases $[11,12]$. In a large series of 5002 conjunctival tumors, there were only $77(1.5 \%)$ childhood or adult papillomas [8]. Despite this small number, papillomas formed a majority of the benign conjunctival epithelial tumors $(77 / 95,81 \%)$ [8].

Ocular surface squamous neoplasia is an umbrella term for premalignant and malignant 
Table 6.1 Classification of conjunctival tumors

\begin{tabular}{|c|c|c|}
\hline Conjunctival tumors & Benign & Malignant \\
\hline \multirow[t]{3}{*}{ Choristomas } & Dermoid & \\
\hline & Dermolipoma & \\
\hline & $\begin{array}{l}\text { Simple and complex } \\
\text { choristoma }\end{array}$ & \\
\hline \multirow[t]{4}{*}{ Epithelial tumors } & Papilloma & \multirow[t]{4}{*}{ Invasive squamous cell carcinoma (SCC) } \\
\hline & Keratoacanthoma & \\
\hline & $\begin{array}{l}\text { Hereditary benign } \\
\text { intraepithelial dyskeratosis }\end{array}$ & \\
\hline & Dacryoadenoma & \\
\hline \multirow[t]{4}{*}{ Melanocytic tumors } & Nevus & \multirow[t]{4}{*}{ Malignant melanoma } \\
\hline & Ocular melanocytosis & \\
\hline & $\begin{array}{l}\text { Complexion-associated } \\
\text { melanosis }\end{array}$ & \\
\hline & Primary acquired melanosis & \\
\hline \multirow[t]{7}{*}{ Vascular tumors } & Pyogenic granuloma & \multirow[t]{7}{*}{ Kaposi sarcoma } \\
\hline & $\begin{array}{l}\text { Lymphangiectasia and } \\
\text { lymphangioma }\end{array}$ & \\
\hline & Varix & \\
\hline & Cavernous hemangioma & \\
\hline & Capillary hemangioma & \\
\hline & Hemangiopericytoma & \\
\hline & Glomus tumor & \\
\hline \multirow{6}{*}{$\begin{array}{l}\text { Neural, xanthomatous, } \\
\text { myxomatous, and lipomatous } \\
\text { tumors }\end{array}$} & Neuroma and neurofibroma & \\
\hline & Schwannoma & \\
\hline & Fibrous histiocytoma & \\
\hline & Lipoma & \\
\hline & Myxoma & \\
\hline & Juvenile xanthogranuloma & \\
\hline \multirow[t]{2}{*}{ Lymphoid and leukemic tumors } & \multirow{2}{*}{$\begin{array}{l}\text { Benign reactive lymphoid } \\
\text { hyperplasia }\end{array}$} & Lymphoid and plasmacytic tumors \\
\hline & & Leukemia \\
\hline \multirow[t]{5}{*}{ Caruncular tumors } & Papilloma & SCC \\
\hline & Nevus & Melanoma \\
\hline & Lipoma & Sebaceous carcinoma \\
\hline & $\begin{array}{l}\text { Sebaceous hyperplasia and } \\
\text { adenoma }\end{array}$ & Lymphoma \\
\hline & Oncocytoma & Kaposi sarcoma \\
\hline Metastatic tumors & & $\begin{array}{l}\text { Tumors metastasizing from primary tumors } \\
\text { located in the breast, lungs, cutaneous } \\
\text { melanoma, etc. }\end{array}$ \\
\hline Secondary tumors & & $\begin{array}{l}\text { Tumors extending from the eyelid, orbit, } \\
\text { intraocular structures, and paranasal sinuses }\end{array}$ \\
\hline
\end{tabular}

epithelial tumors on the eye, including conjunctival intraepithelial neoplasia (CIN) and invasive SCC. CIN is squamous neoplasia that extends through the entire thickness of the conjunctival epithelium but is confined to the epithelium, not invading beyond the basement membrane. On the other hand, invasive SCC has gross or microscopic invasion into the adjacent tissue.
Invasive conjunctival SCC typically presents in the elderly between 60 and 80 years of age. Younger patients with conjunctival SCC often have underlying disease that promotes a risk like immunodeficiency, allowing human papillomavirus (HPV) to proliferate, or xeroderma pigmentosa, with inability to repair DNA alterations. The exact pathogenesis of conjunctival SCC is not known 
but it most commonly occurs in areas with high ultraviolet light B rays exposure [13]. A close association with HPV infection has also been observed [13]. Patients with human immunodeficiency virus (HIV) and other immunodeficient diseases are reported to have recurrent and more aggressive tumors $[13,14]$. There is also a relationship of conjunctival SCC with heavy cigarette smoking.

Clinically, conjunctival SCC typically manifests in the limbal area as a thin or thick placoid lesion with a gelatinous or papillomatous surface, occasionally forming a nodular mass. A clinical variant of this tumor, called diffuse conjunctival SCC, appears flat and gelatinous in a horizontal growth pattern with diffuse thickening of the conjunctiva and corneal surface. This can be mistaken as chronic conjunctivitis, leading to a delay in diagnosis and treatment. Invasive SCC is associated with feeder vessels, intrinsic vascularity, keratin formation, and sometimes surface inflammation. The tumor can extend into the sclera and globe or into the orbit in neglected cases. Rarely, metastasis to regional lymph nodes and distant sites can occur, particularly in immune-deficient patients. The mucoepidermoid variant of SCC tends to be more aggressive and has increased capacity for local invasion [15].

\section{Conjunctival Melanocytic Tumors}

The conjunctival melanocytic tumors include nevus, racial melanosis, primary acquired melanosis, and melanoma. Conjunctival nevus is the most common tumor in both children and adults $[5-7,16]$. In a large clinical review of 5002 cases, nevus accounted for $45 \%(n=1163 / 2590)$ of conjunctival melanocytic lesions and for $23 \%$ of all 5002 conjunctival lesions [8]. Although considered congenital, it frequently becomes clinically apparent in the first or second decade of life, especially if it is gaining pigment. The nevus evolves from a junctional to a compound and then to a subepithelial nevus with age, as the melanocytes migrate from the basal layer of the epithelium into the underlying stroma [17]. It can be pigmented or nonpigmented, and multiple clear intralesional cysts are commonly seen. Shields et al. described 410 consecutive cases of con- junctival nevi and found that the most common location for a nevus was the bulbar conjunctiva (72\%), followed by the caruncle $(15 \%)$, semilunar fold $(11 \%)$, fornix (1\%), tarsus $(1 \%)$, and cornea (1\%). Malignant transformation occurs in less than $1 \%[16,17]$.

Conjunctival primary acquired melanosis (PAM) refers to an acquired conjunctival pigmentation that is flat and noncystic, which does not resemble either a nevus or complexionassociated melanosis (CAM). PAM commonly presents in middle age and is usually unilateral. It can be focal or diffuse, and sometimes multifocal. Rarely, PAM can be nonpigmented. Progression to melanoma occurs when PAM demonstrates severe atypia, and this represents $13-48 \%$ of cases [18, 19].

Conjunctival melanoma arises either de novo or from a preexisting nevus or PAM. Melanoma arising from PAM accounts for $74 \%$ of cases, while those arising from a preexisting nevus and de novo account for $7 \%$ and $19 \%$ of cases, respectively [20]. The presentation is generally in middle-aged or elderly individuals and it appears as a pigmented or fleshy, elevated conjunctival mass with a lobulated surface. The most frequent location of melanoma is on the bulbar conjunctiva, although forniceal or palpebral conjunctiva is occasionally the site of origin [20]. Similar to nevus and PAM, conjunctival melanoma can be amelanotic and the diagnosis is confirmed on histopathology. Conjunctival melanoma is malignant and can metastasize to preauricular and submandibular lymph nodes, and carry potential for remote hematogenous spread to brain, liver, skin, and bone [17].

\section{Conjunctival Lymphoid Tumors}

Conjunctival lymphoma is a clonal proliferation of lymphoid tissue normally present in the conjunctiva. Lymphoid proliferation of the conjunctiva ranges from benign reactive lymphoid hyperplasia (BRLH) to malignant lymphoma. A lymphoid tumor occurring in the conjunctiva can be an isolated condition or a manifestation of generalized systemic disease. In the conjunctiva, the most commonly occurring lymphoma is B-cell 
non-Hodgkin lymphoma (NHL). Of the various subtypes, the most frequent includes extranodal marginal zone lymphoma (ENMZL), follicular lymphoma, diffuse large B-cell lymphoma, and mantle cell lymphoma [21]. Clinically, a lymphoid tumor presents as a diffuse, slightly elevated fleshy salmon-colored mass deep to the epithelium, frequently located in the forniceal or bulbar conjunctiva. A review of 117 patients with conjunctival lymphoma revealed that $31 \%$ eventually developed systemic lymphoma [22].

\section{Caruncle Tumors}

The caruncle is a composite structure that comprises both cutaneous elements such as hair follicles, sebaceous glands, and sweat glands, as also conjunctival tissue including accessory lacrimal gland tissue. Hence, the caruncle is a site for tumors of both skin and conjunctival origin. The common tumors of caruncle include papilloma (32\%), melanocytic nevus (24\%), inclusion cyst (7\%), and oncocytoma (4\%) [23]. Papilloma has a distinct frond-like vascular appearance arranged in hairpin loops. Caruncular nevus or melanoma is often pigmented and nodular. Oncocytoma originates from the accessory lacrimal gland ductal tissue and appears as a reddish blue solid or cystic mass. Sebaceous gland hyperplasia and sebaceous adenoma appear as a yellow mass.

Vascular, neural, fibrous, lipomatous, xanthomatous, metastatic, and secondary tumors of the conjunctiva are rare and together comprise approximately $10 \%$ of all conjunctival tumors [5]. For more information on those tumors, reference to major articles [1, 4-9] and textbooks [10, 17, 24-27] is advised.

\section{References}

1. Shields CL, Shields JA. Tumors of the conjunctiva and cornea. Surv Ophthalmol. 2004;49:3-24.

2. Marshall EC. Epidemiology of tumors affecting the visual system. Optom Clin. 1993;3(3):1-16.

3. Lee SB, Au Eong KG, Saw SM, et al. Eye cancer incidence in Singapore. $\mathrm{Br} \mathrm{J}$ Ophthalmol. 2000;84:767-70.
4. Grossniklaus HE, Green WR, Luckenbach M, Chan CC. Conjunctival lesions in adults. A clinical and histopathologic review. Cornea. 1987;6:78-116.

5. Shields CL, Demirci H, Karatza E, Shields JA. Clinical survey of 1643 melanocytic and nonmelanocytic conjunctival tumors. Ophthalmology. 2004;111(9):1747-54.

6. Shields CL, Shields JA. Conjunctival tumors in children. Curr Opin Ophthalmol. 2007;18(5):351-60.

7. Zimmermann-Paiz MA, García de la Riva JC. Conjunctival tumors in children: histopathologic diagnosis in 165 cases. Arq Bras Oftalmol. 2015;78(6):337-9.

8. Shields CL, Alset AE, Boal NS, et al. Conjunctival tumors in 5002 cases. Comparative analysis of benign versus malignant counterparts. The 2016 James D. Allen lecture. Am J Ophthalmol. 2017;173:106-33.

9. Shields CL, Sioufi K, Alset AE, et al. Clinical features differentiating benign from malignant Conjunctival tumors in children. JAMA Ophthalmol. 2017 Mar $1 ; 135(3): 215-24$.

10. Shields J, Shields C. Conjunctival and epibulbar choristomas. In: Shields J, Shields C, editors. Atlas of eyelid, conjunctival and orbital tumors. 3rd ed. Philadelphia: Lippinoctt/Wolters Kluwer; 2016. p. 251-66.

11. Sjö NC, von Buchwald C, Cassonnet P, et al. Human papilloma virus in normal conjunctival tissue and in conjunctival papilloma: types and frequencies in a large series. Br J Ophthalmol. 2007;91(8):1014-5.

12. Kaliki S, Arepalli S, Shields CL, et al. Conjunctival papilloma: features and outcomes based on age at initial examination. JAMA Ophthalmol. 2013;131(5):585-93.

13. Sun EC, Fears TR, Goedert JJ. Epidemiology of squamous cell conjunctival cancer. Cancer Epidemiol Biomark Prev. 1997;6:73-7.

14. Shields CL, Ramasubramanian A, Mellen PL, Shields JA. Conjunctival squamous cell carcinoma arising in immunosuppressed patients (organ transplant, human immunodeficiency virus infection). Ophthalmology. 2011;118:2133-7.

15. Lee GA, Hirst LW. Ocular surface squamous neoplasia. Surv Ophthalmol. 1995;39:429-50.

16. Shields CL, Fasiudden A, Mashayekhi A, et al. Conjunctival nevi: clinical features and natural course in 410 consecutive patients. Arch Ophthalmol. 2004;122:167-75.

17. Shields J, Shields C. Conjunctival melanocytic lesions. In: Shields J, Shields C, editors. Atlas of eyelid, conjunctival and orbital tumors. 3rd ed. Philadelphia: Lippinoctt/Wolters Kluwer; 2016. p. 307-48.

18. Shields JA, Shields CL, Mashayekhi A, et al. Primary acquired melanosis of the conjunctiva: risks for progression to melanoma in 311 eyes. The 2006 Lorenz E. Zimmerman lecture. Ophthalmology. 2008;115(3):511-9.

19. Folberg R, McLean IW, Zimmerman LE. Primary acquired melanosis of the conjunctiva. Hum Pathol. 1985;16(2):129-35.

20. Shields CL, Markowitz JS, Belinsky I, et al. Conjunctival melanoma: outcomes based on tumor 
origin in 382 consecutive cases. Ophthalmology. 2011;118(2):389-95.e1-2.

21. Kirkegaard MM, Rasmussen PK, Coupland SE, et al. Conjunctival lymphoma-an international multicenter retrospective study. JAMA Ophthalmol. 2016;134(4):406-14.

22. Shields CL, Shields JA, Carvalho C, et al. Conjunctival lymphoid tumors: clinical analysis of 117 cases and relationship to systemic lymphoma. Ophthalmology. 2001;108(5):979-84.

23. Shields CL, Shields JA, White D, et al. Types and frequency of lesions of the caruncle. Am J Ophthalmol. 1986;102:771-8.

24. Shields J, Shields C. Vascular tumors and related lesions of the conjunctiva. In: Shields J, Shields C, editors. Atlas of eyelid, conjunctival and orbital tumors. 3rd ed. Philadelphia: Lippinoctt/Wolters Kluwer; 2016. p. 349-66.

25. Shields J, Shields C. Conjunctival neural, xanthomatous, fibrous, myxomatous, and lipomatous tumors. In: Shields J, Shields C, editors. Atlas of eyelid, conjunctival and orbital tumors. 3rd ed. Philadelphia: Lippinoctt/Wolters Kluwer; 2016. p. 367-78.

26. Shields J, Shields C. Conjunctival lymphoid, leukemic, and metastatic tumors. In: Shields J, Shields $\mathrm{C}$, editors. Atlas of eyelid, conjunctival and orbital tumors. 3rd ed. Philadelphia: Lippinoctt/Wolters Kluwer; 2016. p. 379-92.

27. Shields J, Shields C. Caruncular tumors. In: Shields J, Shields C, editors. Atlas of eyelid, conjunctival and orbital tumors. 3rd ed. Philadelphia: Lippinoctt/ Wolters Kluwer; 2016. p. 394-402.

Open Access This chapter is licensed under the terms of the Creative Commons Attribution 4.0 International License (http://creativecommons.org/licenses/by/4.0/), which permits use, sharing, adaptation, distribution and reproduction in any medium or format, as long as you give appropriate credit to the original author(s) and the source, provide a link to the Creative Commons license and indicate if changes were made.

The images or other third party material in this chapter are included in the chapter's Creative Commons license, unless indicated otherwise in a credit line to the material. If material is not included in the chapter's Creative Commons license and your intended use is not permitted by statutory regulation or exceeds the permitted use, you will need to obtain permission directly from the copyright holder. 